\title{
Enantioselective Copper-Catalyzed Reductive Coupling of Vinylazaarenes with $N$-Boc Aldimines
}

\author{
Bonnie Choi, ${ }^{\text {a,b }}$ Aakarsh Saxena, ${ }^{a}$ Joshua J. Smith, ${ }^{\mathrm{a}, \mathrm{b}}$ Gwydion H. Churchill, ${ }^{\mathrm{c}}$ and Hon Wai Lam*a,b \\ ${ }^{a}$ EaStCHEM, School of Chemistry, University of Edinburgh, Joseph Black Building, The King's Buildings, West Mains Road, \\ Edinburgh EH9 3JJ, UK \\ ${ }^{\mathrm{b}}$ School of Chemistry, University of Nottingham, University Park, Nottingham, NG7 2RD, UK \\ ${ }^{\mathrm{c}}$ AstraZeneca Process Research and Development, Charter Way, Silk Road Business Park, Macclesfield, Cheshire, SK10 2NA, UK \\ Fax +44(115)9513555; E-mail: hon.lam@nottingham.ac.uk \\ Received: The date will be inserted once the manuscript is accepted.
}

\begin{abstract}
The diastereo- and enantioselective reductive coupling of vinylazaarenes with $N$-Boc aldimines is described. The reactions proceed using chiral $\mathrm{Cu}$-bisphosphine complexes in the presence of TMDS as a hydride source to give reductive coupling products in moderate to high enantioselectivities.
\end{abstract}

Key words: asymmetric catalysis, copper, enantioselectivity, imines, vinylazaarenes

The broad significance of aromatic nitrogen heterocycles (azaarenes) in chiral biologically active compounds and other functional molecules has prompted our group to investigate the potential of $\mathrm{C}=\mathrm{N}$-containing azaarenes as activating groups in new catalytic enantioselective processes. ${ }^{1,2}$ During this program, we have reported enantioselective $\mathrm{Cu}$-catalyzed reductions of $\beta, \beta-$ disubstituted alkenylazaarenes ${ }^{2 \mathrm{a}}$ and $\mathrm{Cu}$-catalyzed reductive couplings of alkenylazaarenes with ketones (Scheme 1a). ${ }^{2 \mathrm{~d}}$ This latter process enables the synthesis of products containing an azaarene and two stereogenic centers, including a tertiary alcohol. The ability to employ other types of electrophiles would be beneficial to expand the range of accessible products.

Krische and co-workers have described the racemic Rhcatalyzed hydrogenative coupling of vinylazines with $\mathrm{N}$ sulfonylaldimines (Scheme $1 \mathrm{~b}$ ), ${ }^{3}$ and we envisaged that a related enantioselective variant employing chiral copper hydride chemistry ${ }^{4}$ could be developed. Although the intermolecular reductive aldol reaction ${ }^{5}$ of $\alpha, \beta-$ unsaturated carbonyl compounds, catalyzed by chiral copper-hydride complexes, has been successful, ${ }^{6}$ the corresponding reductive Mannich reactions ${ }^{7}$ have been less well studied. ${ }^{8}$ To date, the only report of enantioselective copper-catalyzed reductive Mannich reactions is from Kanai, Shibasaki, and co-workers, who described the reductive coupling of $\alpha, \beta$-unsaturated esters with $N$-phosphinoyl ketimines. ${ }^{7 f}$

Herein, we describe the enantioselective $\mathrm{Cu}$-catalyzed reductive coupling of vinylazaarenes with $\mathrm{N}$-Boc aldimines. Both vinylazines and vinylazoles are effective substrates, and the Boc-protection in the products is advantageous for subsequent deprotection.

Our investigations began with an evaluation of chiral

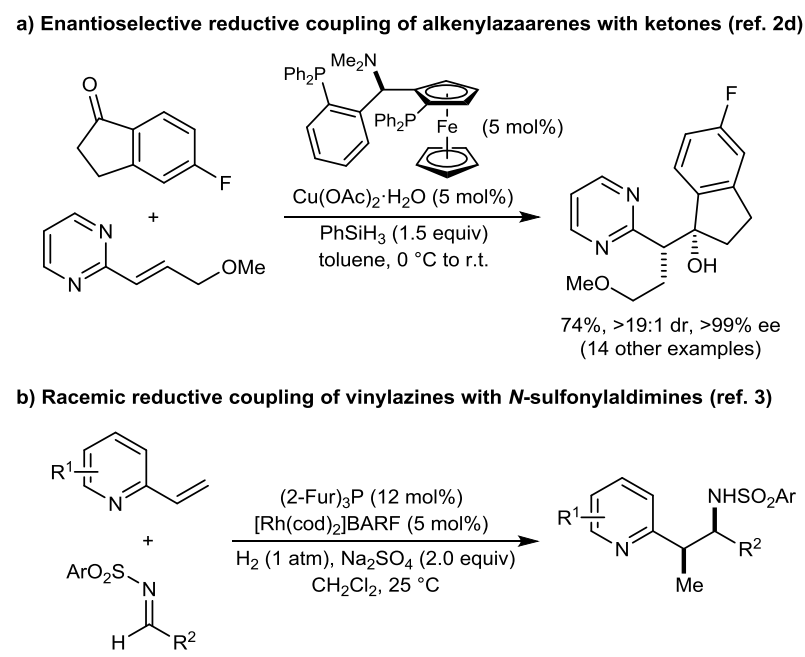

Scheme 1 Existing catalytic reductive coupling reactions of alkenylazaarenes.

bisphosphines, reductants, and reaction conditions for the copper-catalyzed reductive coupling of 2vinylquinoline (1a) with $N$-Boc aldimine 2a (1.1 equiv), which led to the identification of (S)-DTBM-SEGPHOS (L1) as an effective chiral ligand. In the presence of $\mathrm{Cu}(\mathrm{OAc})_{2} \cdot \mathrm{H}_{2} \mathrm{O}(5 \mathrm{~mol} \%), \mathbf{L 1}(5 \mathrm{~mol} \%)$ and $1,1,3,3-$ tetramethyldisiloxane (TMDS, 1.2 equiv), the reaction proceeded smoothly in THF at room temperature to give reductive coupling product 3a as the anti-diastereomer in $63 \%$ yield, $>19: 1 \mathrm{dr}$, and $85 \%$ ee (Scheme 2). ${ }^{9,10}$ Under these conditions, various other vinylazaarenes $\mathbf{1 b}-\mathbf{1 f}$ were also effective in reactions with imine 2a, which gave products $\mathbf{3 b}-\mathbf{3 f}$ in $58-74 \%$ yield and $75-92 \%$ ee. Besides quinolone (3a), azaarenes that were tolerated included quinoxaline (3b), a bromopyridine (3c), a phenylpyridazine (3d), benzoxazole (3e), and benzothiazole (3f). High diastereoselectivities $(\geq 10: 1 \mathrm{dr})$ were observed with vinylazaarenes containing benzannulation (3a, 3b, 3e, and 3f), while 2-bromo-6vinylpyridine and 3-phenyl-6-vinylpyridazine resulted in more modest diastereoselectivities (3c and 3d). In the former case, the diastereomers were difficult to separate completely, and the minor isomer was formed in a much lower enantiomeric excess $(20 \%$ ee) compared with the major isomer $(80 \%$ ee). 


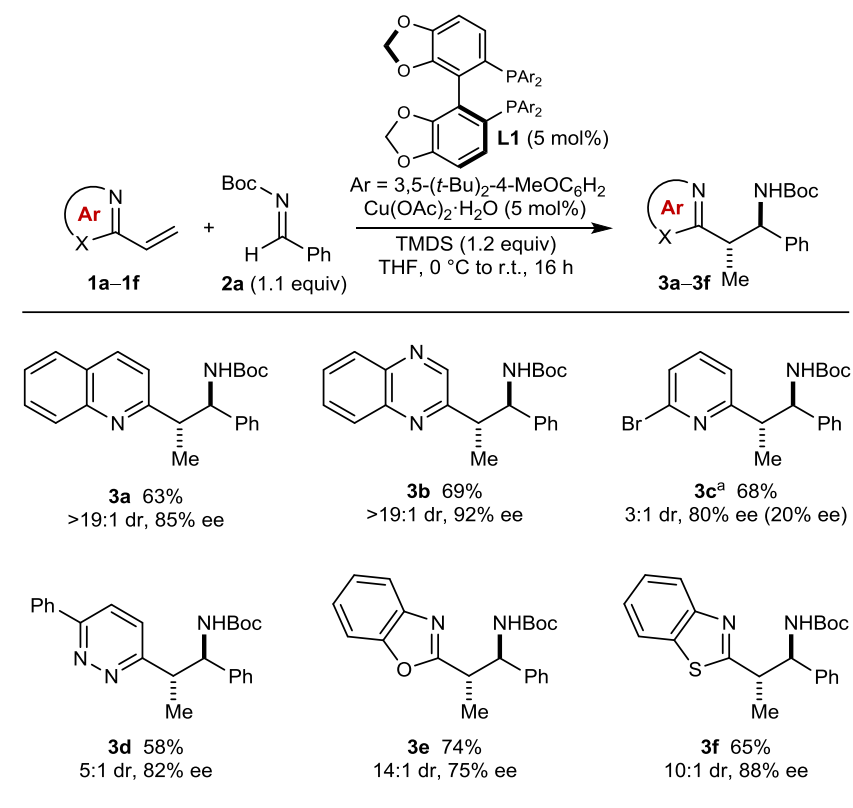

Scheme 2 Enantioselective reductive coupling of vinylazaarenes 1a1f with $N$-Boc imine 2a. Reactions were conducted using $0.30 \mathrm{mmol}$ of 1a-1f. Unless stated otherwise, yields are of pure isolated major diastereomers. Diastereomeric ratios were determined by ${ }^{1} \mathrm{H}$ NMR analysis of the unpurified reaction mixtures. Enantiomeric excesses were determined by chiral HPLC analysis. ${ }^{a}$ Yield of a 4.3:1 mixture of diastereomers. The enantiomeric excess of the minor diastereomer is indicated in parentheses.

The reductive coupling of 4-phenyl-2-vinylthiazole (1g) with imine 2a proceeded with low enantioselectivity using ligand L1. Fortunately, $(R, R)-\mathrm{Ph}-\mathrm{BPE} \quad(\mathbf{L} 2)$ provided improved results, and gave $\mathbf{3 g}$ in $88 \%$ yield, $>19: 1 \mathrm{dr}$, and $87 \%$ ee (Scheme 3$)^{90}$

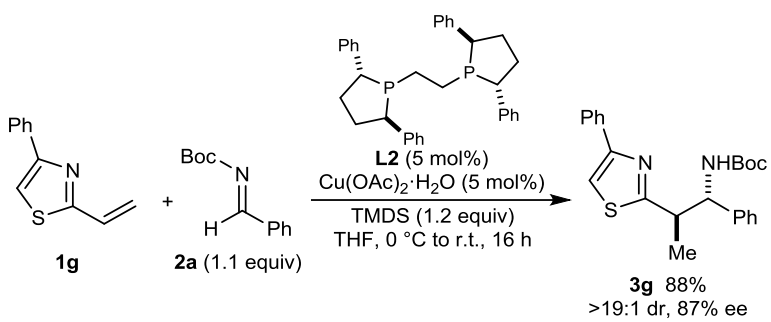

Scheme 3 Reductive coupling of 1 g with 2 a using ligand $\mathbf{L 2}$.

Various other (hetero)aromatic $N$-Boc aldimines $\mathbf{2 b - 2 l}$ also underwent reductive coupling with vinylazaarenes 1a-1f, giving products $\mathbf{4 a}-\mathbf{4 s}$ in $59-94 \%$ ee for the major diastereomers (Scheme 4). ${ }^{10}$ The diastereoselectivities of these reactions ranged from 1.3:1 $\mathrm{dr}(\mathbf{4 i})$ to $>19: 1 \mathrm{dr}(\mathbf{4 a}-$ $\mathbf{4 c}, \mathbf{4 e}, \mathbf{4 f}$, and $4 \mathbf{r})$. Compared with the results shown in Scheme 2 and with similar reactions using ketones as electrophiles, ${ }^{2 \mathrm{~d}}$ these reactions often provided lower yields of the reductive coupling products due to more prevalent side-reactions, such as simple reduction of both reaction partners without $\mathrm{C}-\mathrm{C}$ bond formation. Although no definitive trends could be deduced from the particular combinations of substrates that resulted in the highest enantioselectivities, values of $85 \%$ ee or higher were observed in several cases $(\mathbf{4 a}, \mathbf{4 c}, \mathbf{4 d}, \mathbf{4 i}, \mathbf{4 k}$, and $\mathbf{4 q - 4 s )}$. With respect to the imine, a range of substituents

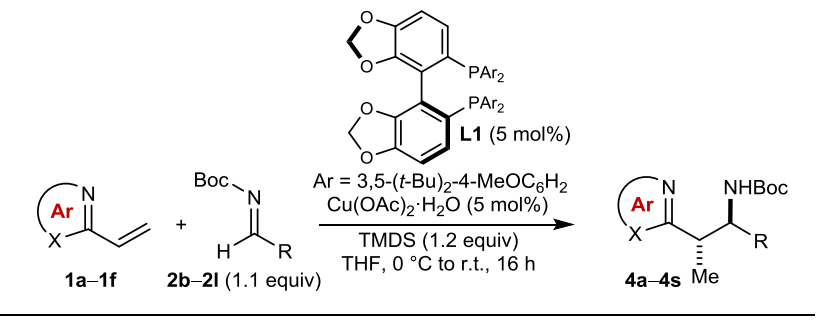

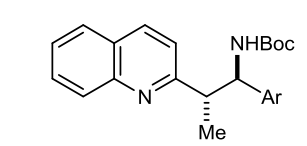

4a $\mathrm{Ar}=2$-naphthyl, $58 \%,>19: 1 \mathrm{dr}, 86 \%$ ee 4b $\mathrm{Ar}=4-\mathrm{MeC}_{6} \mathrm{H}_{4}, 61 \%,>19: 1 \mathrm{dr}, 82 \%$ ee 4c $\mathrm{Ar}=2-\mathrm{ClC}_{6} \mathrm{H}_{4}, 42 \%,>19: 1 \mathrm{dr}, 85 \%$ ee

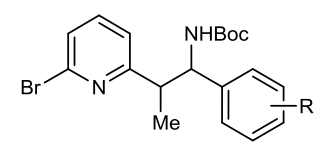

$\mathbf{4 g}^{\mathrm{a}} \mathrm{R}=3-\mathrm{OMe}, 71 \%, 3: 1 \mathrm{dr}, 80 \%(5 \%$ ee $)$ $79 \%(57 \%$ ee) $4 \mathrm{i}^{\mathrm{C}} \quad \mathrm{R}=4-\mathrm{B}(\mathrm{pin}), 56 \%, 1.3: 1 \mathrm{dr}, 85 \%(0 \%$ ee)

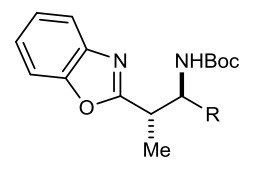

4m R $=2$-thienyl, $71 \%, 10: 1 \mathrm{dr}, 69 \%$ ee 4n R $=2$-naphthyl, $63 \%, 8: 1 \mathrm{dr}, 81 \%$ ee 4o $\mathrm{R}=$ piperonyl, $78 \%, 10: 1 \mathrm{dr}, 79 \%$ ee

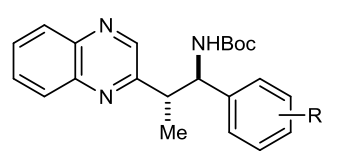

4d $\mathrm{R}=4-\mathrm{CF}_{3}, 46 \%, 5: 1 \mathrm{dr}, 93 \%$ ee 4e $\mathrm{R}=3-\mathrm{OMe}, 59 \%,>19: 1 \mathrm{dr}, 79 \%$ ee 4f $\mathrm{R}=2-\mathrm{Me}, 56 \%,>19: 1 \mathrm{dr}, 80 \%$ ee<smiles>[R]C(NC(=O)OCc1ccccc1)C([N])c1ccccc1</smiles>

4j $\mathrm{R}=2-\mathrm{MeC}_{6} \mathrm{H}_{5}, 51 \%, 5: 1 \mathrm{dr}, 74 \%$ ee $4 \mathbf{k} \mathrm{R}=1$-naphthyl, $35 \%, 6: 1 \mathrm{dr}, 88 \%$ ee 4I $\mathrm{R}=$ piperonyl, $50 \%, 3: 1 \mathrm{dr}, 59 \%$ ee

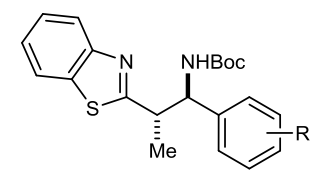

4p $\mathrm{R}=3-\mathrm{Cl}, 42 \%, 6: 1 \mathrm{dr}, 75 \%$ ee 4q $\mathrm{R}=2-\mathrm{Me}, 54 \%, 6: 1 \mathrm{dr}, 94 \%$ ee $4 \mathrm{r} \mathrm{R}=1$-naphthyl, $71 \%,>19.1 \mathrm{dr}, 94 \%$ e 4s $R=4-B($ pin), $40 \%, 3: 1 \mathrm{dr}, 86 \%$ ee
Scheme 4 Enantioselective reductive coupling of vinylazaarenes 1a1f with various $N$-Boc imines. Reactions were conducted using 0.30 mmol of 1a-1f. Unless stated otherwise, yields are of pure isolated major diastereomers. Diastereomeric ratios were determined by ${ }^{1} \mathrm{H}$ NMR analysis of the unpurified reaction mixtures. Enantiomeric excesses were determined by chiral HPLC analysis. Where measured, the enantiomeric excess of the minor diastereomer is indicated in parentheses. ${ }^{a}$ Yield of a 4.7:1 mixture of diastereomers. ${ }^{\mathrm{b}}$ Yield of a 3:1 mixture of diastereomers. ${ }^{c}$ Yield of a 1.6:1 mixture of diastereomers.

(methyl, trifluoromethyl, chloro-, methoxy, dioxolane, or boronate esters) at various positions on the phenyl ring were tolerated. Furthermore, reactions of imines containing 1-naphthyl, 2-naphthyl, or 2-thienyl groups were also successful. As observed previously (Scheme 1), the reactions of 2-bromo-6-vinylpyridine and 3phenyl-6-vinylpyridazine generally gave lower diastereoselectivities (4g-4I) compared with the other vinylazaarenes. Lower diastereoselectivities were also obtained with an imine containing a $p$-pinacol boronic ester (4i and $\mathbf{4 s}$ ). Interestingly, the minor diastereomers obtained for products $\mathbf{4 g}$ and $\mathbf{4 i}$ were obtained in low or non-existent enantiomeric excesses.

Once again, $(R, R)$-Ph-BPE (L2) was a superior ligand compared with $\mathbf{L 1}$ in a reductive coupling involving 4phenyl-2-vinylthiazole (Scheme 5). ${ }^{10}$ 


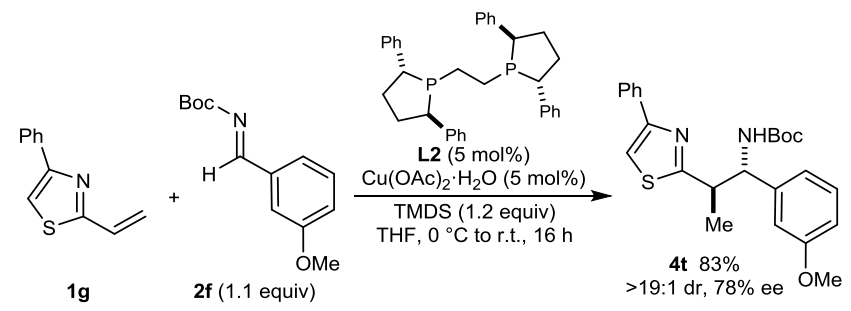

Scheme 5 Reductive coupling of $\mathbf{1 g}$ with $\mathbf{2 f}$ using ligand $\mathbf{L} \mathbf{2}$.

The reaction of 2-vinylbenzothiazole (1f) with an imine 2m (2.0 equiv) containing an aliphatic substituent (cyclohexyl) was also studied (Scheme 6). Although low stereoselectivities were obtained using ligands $\mathbf{L} 1$ or $\mathbf{L 2}$, the Josiphos ligand SL-J006-1 (L3) gave improved results, and provided two diastereomers of $4 \mathbf{u}$ in $73 \%$ and $16 \%$ yields, in $82 \%$ and $75 \%$ ee for the major and minor isomers, respectively.

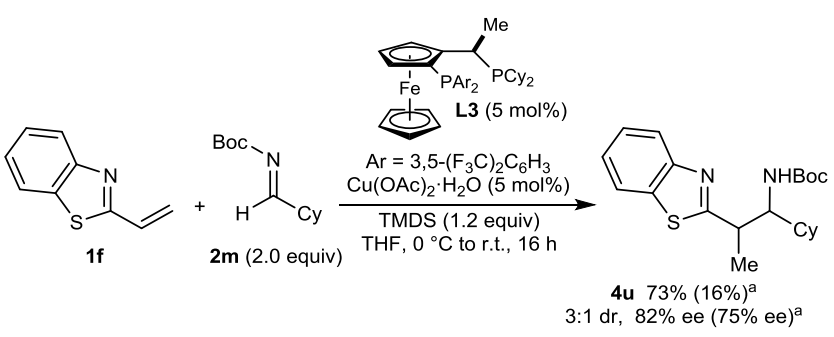

Scheme 6 Reductive coupling of $\mathbf{1 f}$ with an aliphatic $N$-Boc imine $\mathbf{2 m}$ using ligand $\mathbf{L 3}$. ${ }^{\text {a }}$ Values in parentheses refer to the yield and enantiomeric excess of the minor diastereomer.

Finally, removal of the Boc group from $\mathbf{4 a}$ was achieved under acidic conditions (using $\mathrm{HCl}$ generated by the reaction of TMSCl with $\mathrm{MeOH}$ ), which provided amine 5 in $90 \%$ yield with no loss of enantiopurity (Scheme 7).

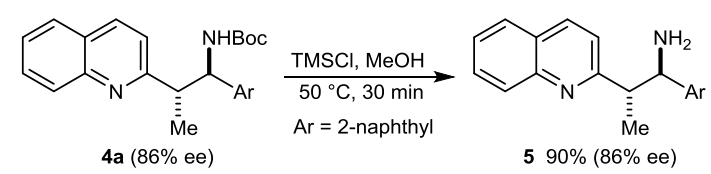

Scheme 7 Deprotection of $\mathbf{4 a}$.

In summary, the results presented herein demonstrate the ability of chiral copper-bisphosphine complexes to catalyze the enantioselective reductive coupling of vinylazaarenes with hetero(aryl) $N$-Boc imines. The reactions provide reductive coupling products with moderate to high enantioselectivities (up to $94 \%$ ee).

\section{Acknowledgment}

We thank the EPSRC, University of Edinburgh, University of Nottingham, AstraZeneca, and GlaxoSmithKline for financial support of this work. We are grateful to Dr. Gary S. Nichol (University of Edinburgh) and Dr. William Lewis (University of Nottingham) for assistance with X-ray crystallography.
Supporting Information for this article is available online at http://www.thiemeconnect.com/products/ejournals/journal/10.1055/s00000083 .

\section{References}

(1) For an overview of $\mathrm{C}=\mathrm{N}$-containing azaarenes as activating groups in enantioselective catalysis, see: Best, D.; Lam, H. W. J. Org. Chem. 2014, 79, 831-845.

(2) For reactions from our group describing the use of $\mathrm{C}=\mathrm{N}$ containing azaarenes as activating groups in enantioselective catalysis, see: (a) Rupnicki, L.; Saxena, A.; Lam, H. W. J. Am. Chem. Soc. 2009, 131, 1038610387. (b) Pattison, G.; Piraux, G.; Lam, H. W. J. Am. Chem. Soc. 2010, 132, 14373-14375. (c) Saxena, A.; Lam, H. W. Chem. Sci. 2011, 2, 2326-2331. (d) Saxena, A.; Choi, B.; Lam, H. W. J. Am. Chem. Soc. 2012, 134, 8428-8431. (e) Fallan, C.; Lam, H. W. Chem. Eur. J. 2012, 18, 11214-11218. (f) Best, D.; Kujawa, S.; Lam, H. W. J. Am. Chem. Soc. 2012, 134, 18193-18196. (g) Roy, I. D.; Burns, A. R.; Pattison, G.; Michel, B.; Parker, A. J.; Lam, H. W. Chem. Commun. 2014, 50, 2865-2868.

(3) Komanduri, V.; Grant, C. D.; Krische, M. J. J. Am. Chem. Soc. 2008, 130, 12592-12593.

(4) For reviews of copper hydride chemistry, see: (a) Lipshutz, B. H. Synlett 2009, 509-524. (b) Deutsch, C.; Krause, N.; Lipshutz, B. H. Chem. Rev. 2008, 108, 29162927. (c) Rendler, S.; Oestreich, M. Angew. Chem., Int. Ed. 2007, 46, 498-504. (d) Lipshutz, B. H. In Modern Organocopper Chemistry; Wiley-VCH Verlag GmbH: 2002, p 167-187.

(5) For selected reviews on reductive aldol reactions, see: (a) Krische, M. J.; Jang, H. Y. In Comprehensive Chirality; Carreira, E. M., Yamamoto, H., Eds.; Elsevier: Amsterdam, 2012, p 100-121. (b) Nishiyama, H.; Ito, J.-i. Chem. Commun. 2010, 203-212. (c) Han, S. B.; Hassan, A.; Krische, M. J. Synthesis 2008, 2669-2679. (d) Garner, S. A.; Han, S. B.; Krische, M. J. In Modern Reduction Methods; Wiley-VCH Verlag GmbH \& Co. KGaA: 2008, p 387-417. (e) Nishiyama, H.; Shiomi, T. Top. Curr. Chem. 2007, 279, 105-137. (f) Ngai, M.-Y.; Kong, J.-R.; Krische, M. J. J. Org. Chem. 2007, 72, 1063-1072.

(6) For intermolecular copper-catalyzed reductive aldol reactions, see: (a) Zhao, D.; Oisaki, K.; Kanai, M.; Shibasaki, M. Tetrahedron Lett. 2006, 47, 1403-1407. (b) Welle, A.; Diez-Gonzalez, S.; Tinant, B.; Nolan, S. P.; Riant, O. Org. Lett. 2006, 8, 6059-6062. (c) Chuzel, O.; Deschamp, J.; Chausteur, C.; Riant, O. Org. Lett. 2006, 8, 5943-5946. (d) Deschamp, J.; Chuzel, O.; Hannedouche, J.; Riant, O. Angew. Chem., Int. Ed. 2006, 45, 1292-1297. (e) Zhao, D.; Oisaki, K.; Kanai, M.; Shibasaki, M. J. Am. Chem. Soc. 2006, 128, 14440-14441. (f) Li, Z.; Jiang, L.; Li, Z.; Chen, H. Chin. J. Chem. 2013, 31, 539-544. (g) Li, Z.; Zhang, Z.; Yuan, L.; Jiang, L.; Li, Z.; Li, Z. Synlett 2014, 25, 724-728.

(7) For examples of catalytic reductive Mannich reactions, see: (a) Muraoka, T.; Kamiya, S.-i.; Matsuda, I.; Itoh, K. Chem. Commun. 2002, 1284-1285. (b) Townes, J. A.; Evans, M. A.; Queffelec, J.; Taylor, S. J.; Morken, J. P. Org. Lett. 2002, 4, 2537-2540. (c) Nishiyama, H.; Ishikawa, J.; Shiomi, T. Tetrahedron Lett. 2007, 48, 78417844. (d) Garner, S. A.; Krische, M. J. J. Org. Chem. 2007, 72, 5843-5846. (e) Prieto, O.; Lam, H. W. Org. Biomol. Chem. 2008, 6, 55-57. (f) Du, Y.; Xu, L.-W.; 
Shimizu, Y.; Oisaki, K.; Kanai, M.; Shibasaki, M. J. Am. Chem. Soc. 2008, 130, 16146-16147.

(8) For related enantioselective copper-catalyzed reductive hydroamination reactions, see: (a) Miki, Y.; Hirano, K.; Satoh, T.; Miura, M. Angew. Chem., Int. Ed. 2013, 52, 10830-10834. (b) Zhu, S.; Niljianskul, N.; Buchwald, S. L. J. Am. Chem. Soc. 2013, 135, 15746-15749. (c) Miki, Y.; Hirano, K.; Satoh, T.; Miura, M. Org. Lett. 2014, 16, 1498-1501.

(9) General Procedure for the Reductive Coupling of Vinylazaarenes with Imine 2a Using Ligand L1 A solution of the appropriate vinylazaarene $(0.30 \mathrm{mmol})$, $\mathrm{Cu}(\mathrm{OAc})_{2} \cdot \mathrm{H}_{2} \mathrm{O}(3.0 \mathrm{mg}, 0.01 \mathrm{mmol}),(S)$-DTBMSEGPHOS (L1) $(17.7 \mathrm{mg}, 0.015 \mathrm{mmol})$, and imine 2a (68 $\mathrm{mg}, 0.33 \mathrm{mmol})$ in THF $(1.5 \mathrm{~mL})$ was stirred at $0{ }^{\circ} \mathrm{C}$ for $15 \mathrm{~min}$. TMDS ( $64 \mu \mathrm{L}, 0.36 \mathrm{mmol})$ was then added dropwise over $1 \mathrm{~min}$. The mixture was stirred at $0{ }^{\circ} \mathrm{C}$ for $1 \mathrm{~h}$, then at r.t. for $15 \mathrm{~h}$. The reaction was quenched carefully with $\mathrm{SiO}_{2}$ and the resulting suspension was stirred for $15 \mathrm{~min}$, before being filtered through a short plug of $\mathrm{SiO}_{2}$ using EtOAc as eluent and concentrated in vacuo. Purification of the residue by flash column chromatography gave the reductive coupling product. Data for 3a: $R_{f}=(20 \% \mathrm{EtOAc} /$ petroleum ether $) ; \mathrm{mp}$ $128-131{ }^{\circ} \mathrm{C}$ (EtOAc/petroleum ether); $[\alpha]_{\mathrm{D}}{ }^{24}+98.6(c$ 1.10, $\mathrm{CHCl}_{3}$ ); IR (film): 2970, 2934, 1709 (C=O), 1503, 1390, 1289, 827, 756, $700 \mathrm{~cm}^{-1}$; ${ }^{1} \mathrm{H}$ NMR $(500 \mathrm{MHz}$, $\left.\left(\mathrm{CD}_{3}\right)_{2} \mathrm{CO}\right): \delta=8.14(\mathrm{~d}, J=8.4 \mathrm{~Hz}, 1 \mathrm{H}), 8.05(\mathrm{~d}, J=8.3$ $\mathrm{Hz}, 1 \mathrm{H}), 7.88(\mathrm{~d}, J=8.0 \mathrm{~Hz}, 1 \mathrm{H}), 7.75(\mathrm{ddd}, J=8.4$, 6.9, $1.4 \mathrm{~Hz}, 1 \mathrm{H}), 7.57-7.51(\mathrm{~m}, 1 \mathrm{H}), 7.33(\mathrm{~d}, J=7.3 \mathrm{~Hz}$, $2 \mathrm{H}), 7.24(\mathrm{t}, J=8.0 \mathrm{~Hz}, 3 \mathrm{H}), 7.16(\mathrm{t}, J=7.0 \mathrm{~Hz}, 2 \mathrm{H})$, $5.09(\mathrm{t}, J=7.7 \mathrm{~Hz}, 1 \mathrm{H}), 3.63-3.54(\mathrm{~m}, 1 \mathrm{H}), 1.35(\mathrm{~d}, J=$ $6.9 \mathrm{~Hz}, 3 \mathrm{H}), 1.27(\mathrm{~s}, 9 \mathrm{H}) ;{ }^{13} \mathrm{C}$ NMR $(125.8 \mathrm{MHz}$, $\left.\left(\mathrm{CD}_{3}\right)_{2} \mathrm{CO}\right): \delta=165.1,156.0,148.5,144.1,137.0,130.2$, 129.7, 128.9, 128.6, 128.0, 127.7, 127.5, 126.8, 122.8, 78.5, 60.2, 48.1, 28.5, 19.6; HRMS (ESI) $\mathrm{m} / \mathrm{z}$ calcd for $\mathrm{C}_{23} \mathrm{H}_{27} \mathrm{~N}_{2} \mathrm{O}_{2}[\mathrm{M}+\mathrm{H}]^{+}: 363.2067$, found: 363.2067; HPLC: Chiralcel OD-H column (90:10 iso-hexane: $i-\mathrm{PrOH}$, $1.0 \mathrm{~mL} / \mathrm{min}, 254 \mathrm{~nm}, 25^{\circ} \mathrm{C}$ ); $t_{\mathrm{R}}$ (major) $=4.6 \mathrm{~min}, t_{\mathrm{R}}$ (minor) $=5.9 \mathrm{~min} ; 85 \%$ ee.

Data for 3f: $R_{f}=0.32(20 \%$ EtOAc/petroleum ether $)$; $\mathrm{mp}$ $142-145^{\circ} \mathrm{C}$ (EtOAc/petroleum ether); $[\alpha]_{\mathrm{D}}{ }^{24}+55.0(c$ 1.00, $\mathrm{CHCl}_{3}$ ); IR (film): 2979, 2928, 1713 (C=O), 1498, $1390,1365,1170,1022,759,700 \mathrm{~cm}^{-1} ;{ }^{1} \mathrm{H}$ NMR $(400$ $\left.\mathrm{MHz},\left(\mathrm{CD}_{3}\right)_{2} \mathrm{CO}\right): \delta=7.98(\mathrm{t}, J=8.9 \mathrm{~Hz}, 2 \mathrm{H}), 7.54-7.45$ $(\mathrm{m}, 1 \mathrm{H}), 7.45-7.35(\mathrm{~m}, 3 \mathrm{H}), 7.30(\mathrm{t}, J=7.4 \mathrm{~Hz}, 2 \mathrm{H})$, $7.23(\mathrm{t}, J=7.5 \mathrm{~Hz}, 1 \mathrm{H}), 6.80(\mathrm{~d}, J=7.5 \mathrm{~Hz}, 1 \mathrm{H}), 5.15-$ $4.90(\mathrm{~m}, 1 \mathrm{H}), 3.88-3.65(\mathrm{~m}, 1 \mathrm{H}), 1.37(\mathrm{~d}, J=6.8 \mathrm{~Hz}, 3$ $\mathrm{H}), 1.28(\mathrm{~s}, 9 \mathrm{H}) ;{ }^{13} \mathrm{C} \mathrm{NMR}\left(125.8 \mathrm{MHz},\left(\mathrm{CD}_{3}\right)_{2} \mathrm{CO}\right): \delta=$ 174.7, 155.9, 154.1, 142.9, 135.6, 129.1, 128.0, 127.8, 126.8, 125.7, 123.4, 122.6, 78.9, 60.3, 45.1, 28.5, 19.5; HRMS (ESI) $m / z$ calcd for $\mathrm{C}_{21} \mathrm{H}_{25} \mathrm{~N}_{2} \mathrm{O}_{2} \mathrm{~S}[\mathrm{M}+\mathrm{H}]^{+}$: 369.1631, found: 369.1634 ; HPLC: Chiralpak IC column (98:2 hexane: $i-\mathrm{PrOH}, 0.8 \mathrm{~mL} / \mathrm{min}, 280 \mathrm{~nm}, 25^{\circ} \mathrm{C}$ ); $t_{\mathrm{R}}$ $($ major $)=18.9 \mathrm{~min}, t_{\mathrm{R}}($ minor $)=27.9 \mathrm{~min} ; 88 \%$ ee.

(10) Where indicated, the relative and absolute stereochemistries of the products were assigned by analogy with those of products $3 f, 3 g, 4 d, 4 k, 4 q$, and $\mathbf{4 t}$, which were determined by X-ray crystallography (see Supporting Information for details). CCDC 10197311019736 contain the supplementary crystallographic data for this paper These data can be obtained free of charge from the Cambridge Crystallographic Data Centre via www.ccdc.cam.ac.uk/data_request/cif or by writing to the Cambridge Crystallographic Data Centre, 12, Union
Road, Cambridge CB2 1EZ, UK; fax: +44(1223)336033; E-mail: deposit@ccdc.cam.ac.uk 